\title{
PERANAN ASPEK MORALITAS, KEPATUHAN, DAN PEMAHAMAN WAJIB PAJAK PRIBADI DALAM PELAPORAN PAJAK PENGHASILAN
}

\author{
Ismail Rasulong ${ }^{1}$, lisdayanti ${ }^{2}$ \\ Universitas Muhammadiyah Makassar \\ e-mail: 1ismailrasulong@unismuh.ac.id, ${ }^{2}$ lisdayanti@unismuh.ac.id
}

\section{Abstract}

This study aims to determine the role of aspects of morality, compliance and understanding of personal taxpayers in the income tax reporting. The method used is qualitative descriptive method by conducting data collection ie questionnaires, documents and observations. The Results of research conducted show that from the aspect of morality, compliance and understanding of taxpayers in KPP Pratama south of Makassar is still low because the taxpayers of individuals registered on KPP Pratama south of Makassar, less inculcate awareness from within themselves to pay taxes.

Keywords : Morality, Compliance, Understanding, Tax Reporting

\begin{abstract}
Penelitian ini bertujuan mengetahui peran aspek moralitas, kepatuhan dan pemahaman wajib pajak pribadi dalam laporan pajak penghasilan. Metode yang digunakan yaitu metode kualitatif diskriptif dengan menggunakan teknik pengumpulan data yaitu menggunakan kuesioner, dokumen, dan pengamatan. Hasil Dari penelitian yang dilakukan menunjukkan bahwa dilihat dari aspek moralitas, kepatuhan dan pemahaman wajib pajak di KPP Pratama Makassar Selatan masih rendah, karena wajib pajak orang pribadi yang terdaftar pada KPP Pratama Makassar Selatan, kurang menanamkan kesadaran dari dalam diri mereka untuk membayar pajak.
\end{abstract}

Keywords : moralias, kepatuhan, pemahaman, pelaporan pajak 


\section{PENDAHULUAN}

Pajak memiliki peranan utama dalam pembangunan dan pembiayaan pengeluaran pemerintah dengan maksud mensejahterakan rakyat. Pajak merupakan pungutan yang dilakukan oleh negara kepada rakyat yang bersifat memaksa. Pajak sangat penting bagi pembangunan negara Indonesia karena pajak memberikan kontribusi terbesar bagi pendapatan negara.

Kebutuhan pembangunan yang semakin hari semakin meningkat dan permasalahan ekonomi negara mendorong pemerintah untuk melakukan berbagai upaya dalam mendapatkan penerimaan negara, Upaya pemerintah dalam meningkatkan dan mengoptimalkan pendapatan negara dapat dilihat dari berbagai peraturan yang dikeluarkan oleh pemerintah. Peraturan perundang-undangan terkait dengan pajak penghasilan dan dasar perhitungan pajak selalu dirubah. Undang-undang nomor 36 tahun 2008 yang merupakan perubahan keempat dari undang-undang nomor 7 tahun 1983 tentang pajak penghasilan. Adanya perubahan peraturan perpajakan nasional yang paling mendasar dan penting adalah pelaksanaan pemungutan pajak, yaitu perubahan dari official assesment system menjadi self assesment system.

Perpajakan indonesia menganut self assesment system yang mana wajib pajak diberikan wewenang untuk melaporkan dan membayar sendiri kewajiban pajak. Salah satu kendala yang dapat menghambat keefektifan pengumpulan pajak adalah kepatuhan wajib pajak (tax compliance). Kepatuhan wajib pajak merupakan persoalan yang sejak dulu ada di Perpajakan. Kemauan wajib pajak dalam membayar pajak merupakan hal yang penting menurut undang-undang pajak penghasilan telah menetapkan sistem pemungutan pajak penghasilan secara Self Assesment System. Tentu sistem yang digunakan memerlukan kejujuran dan kesadaran wajib pajak dari perhitungan pajak sampai pelaporan dalam SPT tahunan.

Belum tercapainya APBN (Anggara Pendapatan Belanja Negara) disebabkan karena berbagai permasalahan ekonomi, hukum dan faktor lainnya. Kebijakan yang efektif bagi wajib pajak orang pribadi seharusnya tidak hanya menekankan pada aspek ekonomi semata (seperti ancaman denda dan pemeriksaan) namun juga memperhatikan aspek keperilakuan (behavioral). Moral perpajakan merupakan kunci yang dapat menjelaskan mengapa orang jujur dalam masalah perpajakan.

Upaya pendidikan, penyuluhan dan sebagainya tidak banyak berarti dalam membangun kesadaran dan kepatuhan wajib pajak untuk ikut serta dalam meningkatkan penerimaan pajak. Masyarakat cenderung menghindari pelaporan dan pembayaran pajak dengan anggapan bahwa mereka tidak menikmati dan merasakan manfaat secara langsung dari pembayaran pajak. Disisi lain ancaman, hukuman, maupun sanksi dalam undang-undang sudah cukup jelas terhadap wajib pajak yang bandel mengabaikan kewajiban pajak. Akan tetapi aturan tersebut tidak sertamerta diindahkan oleh masyarakat khususnya wajib pajak orang pribadi yang sudah seharusnya melaporkan dan membayar pajak sesuai dengan aturan pajak yang berlaku.

Sekarang ini penghasilan yang didapat oleh orang tidak hanya berdasarkan penghasilan atas pekerjaan di suatu perusahaan atau suatu lembaga saja. Optimalisasi penerimaan pajak dapat ditingkatkan melalui pemungutan pajak penghasilan yang berkaitan dengan pekerjaan bebas. Penghasilan yang diperoleh dari pekerjaan bebas dilaporkan dalam surat pemberitahuan dan dibayarkan pajaknya dengan cara disetahunkan. Pelaporan dan pembayaran pajak atas penghasilan dari pekerjaan bebas tersebut dapat meningkatkan penerimaan pajak. Dilihat dari wilayah Kantor pelayanan pajak makassar, sebagian besar memiliki pekerjaan yang berkaitan dengan pekerjaan bebas atau pekerjaan atas keahlian yang dimiliki. 
Penghasilan atas pekerjaan bebas atau penghasilan sampingan ini haruslah dilaporkan dan dibayarkan pajak terhutangnya. Kewajiban untuk membayar pajak dan melaporkannya dalam SPT Tahunan wajib pajak orang pribadi adalah seluruh penghasilan yang diterima oleh wajib pajak baik itu penghasilan tetap atas pekerjaan maupun penghasilan sampingan. Artinya, setiap orang yang memiliki penghasilan sampingan diwajibkan untuk melaporkan dan membayarkan $\mathrm{PPh}$ atas pajak penghasilannya tersebut. Penghasilanpenghasilan tersebut harus dilaporkan dalam surat pemberitahuan sebagaimana dijelaskan dalam undang-undang no 46 tahun 2013 dan dikenakan pajak.

Seseorang yang bekerja disuatu perusahaan, pajaknya sudah dipotong oleh perusahaan dan perusahaan memberikan bukti dari pemotongan pajaknya, berbeda halnya dengan penghasilan sampingan. Bagaimana cara menghitung pajak atas penghasilan sampingan kita tahu bahwa sebagian besar penghasilan sampingan tidak menentu setiap bulannya dan tidak adanya bukti yang menunjukan besarnya penghasilan sampingan itu sendiri. Sulit untuk membuktikan kepada Kantor Pelayanan Pajak (KPP) mengenai besarnya penghasilan yang diterima, pembuktian besaran penghasilannya hanya tergantung dengan kejujuran wajib pajaknya saja.

\section{TINJAUAN PUSTAKA}

\section{Theory of planned behaviour (teori perilaku terencana )}

Ajzen (budi wahyono:2014) menyatakan Theory of planned behaviour merupakan teori yang mendasari tentang niat dalam melakukan suatu perbuatan yang di kendalikan oleh kemauan dari dalam diri individu. Theory of planned behaviour merupakan perluasan dari theory of reasoned action $\mathrm{d}$ ibuat diperlukan oleh model asli keterbatasan dalam berurusan dengan perilaku dimana orang tidak memiliki kendali penuh kehendak.
Theory of Planned Behavior merupakan perluasan dari Theory of Reasoned Action. Dalam Theory of Reasoned Action dijelaskan bahwa niat seseorang terhadap perilaku dibentuk oleh dua faktor utama yaitu attitude toward the behavior dan subjective norms sedangkan dalam Theory of planned behaviour ditambahkan satu faktor lagi yaitu perceived behavioral control.

Niat atas perilaku dapat memberikan gambaran atas apa yang dilakukan seseorang, terkait dengan perilaku untuk melakukan tindakan atau tidak. Teori ini didasari oleh niat yang berasal dari dalam diri seseorang mengenai tindakan yang akan dilakukan. Ada tiga faktor penentu niat yang berdiri sendiri, yaitu sikap terhadap perilaku (attitude toward the behaviour), norma subjektif (subjektif norm), dan kontrol perilaku yang dipersepsikan (perceived behavioral control).

a. Sikap terhadap perilaku (attitude toward the behaviour)

Keyakinan-keyakinan perilaku (behaviour beliefs) yang kemudian menghasilkan sikap terhadap perilaku (attitude toward behavior) adalah keyakinan individu akan hasil dari suatu perilaku dan evaluasi atas hasil tersebut (beliefs strength and outcome evaluation), apakah perilaku tersebut positif atau negatif. Keyakinan atas segala sesuatu yang akan dilakukan itu berasal dari dalam diri individu masing-masing.

b. Norma subyektif

Keyakinan normatif (normative beliefs) adalah keyakinan tentang harapan normatif orang lain yang memotifasi seseorang untuk memenuhi harapan tersebut (normative beliefs and motivation to comply). Keyakinan normatif merupakan indikator yang kemudian menghasilkan norma subjektif. Jadi norma subjektif adalah persepsi seseorang tentang pengaruh sosial dalam membentuk perilaku tertentu. Seseorang bisa terpengaruh atau tidak terpengaruh oleh tekanan sosial.

c. Kontrol perilaku yang dipersepsikan

Keyakinan kontrol (control beliefs) yang kemudian melahirkan kontrol perilaku yang 
dipersepsikan adalah keyakinan tentang keberadaan hal-hal yang mendukung atau menghambat perilaku yang akan ditampilkan dan persepsinya tentang seberapa kuat hal-hal yang mendukung dan menghambat perilakunya tersebut (perceived power).

Berdasarkan theory of planned bahavior, dapat dijelaskan bahwa perilaku individu untuk tidak patuh, jujur dan memiliki kesadaran serta pemahaman terhadap ketentuan perpajakan dipengaruhi oleh niat (intention). Niat untuk berperilaku dipengaruhi oleh tiga faktor yaitu:

a. Behavioral belief, yaitu keyakinan akan hasil dari suatu perilaku (outcome belief) dan evaluasi terhadap hasil perilaku tersebut. Keyakinan dan evaluasi terhadap hasil ini akan membentuk variabel sikap (attitude) terhadap perilaku itu. Wajib pajak memperhatikan dan mengawasi pemerintah dalam menjalankan amanah untuk mengelolah dana pajak. Wajib pajak akan membayar pajak ketika kinerja pemerintah bagus dalam hal ini ada output yang dihasilkan dan nampak dari apa yang mereka bayarkan.

b. Normative belief, yaitu keyakinan individu terhadap harapan normatif orang lain yang menjadi rujukannya, seperti keluarga, teman, dan konsultan pajak, dan motivasi untuk mencapai harapan tersebut. Harapan normatif ini membentuk variabel norma subjektif (subjektive norm) atas suatu perilaku. Pelayanan pemerintah memberikan kontribusi besar dalam optimalisasi penerimaan pajak. Wajib pajak yang dilayani dengan baik, dan mudah dalam memahami aturan pajak akan merasa nyaman dan mau membayar pajak. Keluarga, teman, dan orang-orang disekelilingnya yang taat membayar pajak akan memberikan motivasi kepada wajib pajak lainnya untuk ikut andil dalam membayar pajak.

c. Control belief, yaitu keyakinan individu tentang keberadaan hal-hal yang mendukung atau menghambat perilakunya dan persepsinya tentang seberapa kua thalhal tersebut mempengaruhi perilakunya. Control belief membentuk variabel kontrol perilaku yang dipersepsikan (perceived behavioral control). Pemerintah yang memegang amanah besar dari masyarakat atau wajib pajak untuk mengelola dana yang mereka berikan sebagai dana negara harus menjaga kepercayaan dan berprilaku yang layak dimata wajib pajak.

d. Kepercayaan wajib pajak terhadap pemerintah sangat diperlukan untuk mengotimalkan penerimaan pajak negara. Perilaku pemerintah saat ini sudah cukup membuat wajib pajak kebingungan dengan maraknya berbagai kasus penggelapan uang negara yang mana dana tersebut dianggarkan untuk pembangunan negara demi kesejahteraan rakyat namun justru dinikmati sendiri oleh pihak-pihak yang tidak bertanggung jawab. Olehnya itu, keyakinan wajib pajak atas transparansi dan akuntabilitas pemerintah saat ini sudah mulai berkurang. Hal ini dapat menyebabkan timbulnya prilaku atau sikap serta motivasi bagi wajib pajak untuk tidak membayar kewajibannya dan melakukan pelanggaran aturan perpajakan. Oleh karena itu kepercayaan kedua belah pihak sangat diperlukan.

e. Niat diasumsikan sebagai faktor motivasi yang mempengaruhi prilaku diantaranya bagaimana orang-orang bersedia untuk mencoba, berapa besar upaya, dan rencana untuk melakukan atau mengerjakan sesuatu. Semakin besar keinginan untuk mengerjakannya maka semakin besar pula kemungkinan untuk merealisasikannya. Pencapaian perilaku tergantung pada motivasi (niat) dan kemampuan baik secara materi maupun non materi. Wajib pajak yang memiliki niat dan kemampuan akan termotivasi untuk membayar kewajibannya.

\section{Pengertian Pajak}

Pajak mempunyai definisi yang berbedabeda menurut sudut pandang yang 
dikemukakan oleh para ahli. Namun pada dasarnya definisi tersebut mempunyai tujuan yang sama yaitu mendefinisikan pengertian pajak agar lebih mudah dipahami. Pajak menurut kamus besar Bahasa Indonesia adalah pungutan wajib,biasanya berupa uang yang harus dibayar oleh penduduk sebagai sumbangan wajib kepada negara atau pemerintah sehubungan dengan pendapatan, pemilikan, harga beli barang, dan sebagainya.

Pajak menurut pasal 1 ayat 1 UU No. 6 tahun 1983 sebagaimana telah disempurnakan terakhir dengan UU No. 16 tahun 2009 tentang Ketentuan Umum dan Tata Cara Perpajakan, kontribusi wajib kepada negara yang terutang oleh orang pribadi atau badan yang bersifat memaksa berdasarkan Undang-Undang, dengan tidak mendapatkan imbalan secara langsung dan digunakan untuk keperluan negara bagi sebesar-besarnya kemakmuran rakyat.

Rochmat

Soemitro

(2016:3) mengemukakan, pajak merupakan iuran rakyat kepada kas negara berdasarkan undangundang (yang dapat dipaksakan) dengan tiada mendapat jasa timbal (kontraprestasi) yang langsung dapat ditunjukkan dan yang digunakan untuk membayar pengeluaran umum. Siti Resmi (2016:1) defenisi tersebut kemudian disempurnakan menjadi, Pajak adalah peralihan kekayaan dari pihak rakyat kepada kas negara untuk membiayai pengeluaran rutin dan surplus nya digunakan untuk public saving yang merupakan sumber utama untuk membiayai public investment. Sedangkan menurut Mardiasmo (2013:1), Pajak merupakan iuran rakyat kepada kas negara berdasarkan Undang-Undang yang dapat dipaksakan dengan tidak mendapat jasa timbal secara langsung yang digunakan untuk membayar pengeluaran umum.

Menurut Soeparman Soemahamidjaja dalam Waluyo dan Wirawan(2015:5) mengemukakan, Pajak adalah iuran wajib berupa uang atau barang yang dipungut oleh penguasa berdasarkan norma-norma hukum, guna menutup biaya produksi barang-barang dan jasa-jasa kolektif dalam mencapai kesejahteraan umum. Menurut Adriani dalam buku Sumarsan, (2013: 3), Pajak adalah iuran kepada negara (yang dapat dipaksakan) yang terutang oleh yang wajib membayarnya menurut peraturan-peraturan, dengan tidak mendapat prestasi kembali, yang langsung dapat ditunjuk, dan yang gunanya adalah untuk membiayai pengeluaran-pengeluaran umum berhubung tugas negara untuk menyelenggarakan pemerintahan.

Dari definisi tersebut, dapat disimpulkan bahwa pajak memiliki unsurunsur:

a. Iuran dari rakyat kepada negara.

b. Yang berhak memungut hanyalah negara, iuran tersebut berupa uang (bukan barang).

c. Berdasarkan undang-undang

d. Pajak dipungut berdasarkan atau dengan kekuatan undang- undang serta aturan pelaksanaanya .

e. Tanpa jasa timbal atau kontraprestasi dari negara yang secara langsung dapat di tunjuk. Dalam pembayaran pajak pajak tidak dapat ditunjukkan adanya kontraprestasi individual oleh pemerintah.

f. Pajak dipungut oleh negara baik pemerintah pusat maupun pemerintah daerah.

g. Pajak diperuntukkan bagi pengeluaranpengeluaran pemerintah, yang bila dari pemasukannya masih terdapat surplus, dipergunakan untuk membiayai public investment.

\section{Fungsi pajak}

Pajak memiliki peranan yang penting dalam kehidupan bernegara, khususnya di dalam pelaksanaan pembangunan karena pajak merupakan sumber pendapatan Negara untuk membiayai semua pengeluaran termasuk pengeluaran pembangunan. Fungsi pajak menurut Mardiasmo (2013:1),yaitu:

a. Fungsi anggaran (budgetair)

Pajak berfungsi sebagai salah satu sumber dana bagi pemerintah untuk membiayai pengeluaran-pengeluarannya. 
b. Fungsi mengatur (regulerend)

Pajak berfungsi sebagai alat untuk mengatur dan melaksanakan kebijaksanaan pemerintah dalam bidang sosial dan ekonomi.

\section{Pengelompokan pajak}

Menurut Mardiasmo (2013:5), pajak dapat dikelompokkan menjadi tiga kelompok sebagai berikut:

a. Menurut golongannya

Pajak langsung, yaitu pajak yang harus dipikul sendiri oleh wajib pajak dan tidak dapat dibebankan atau dilimpahkan kepada orang lain. Pajak tidak langsung, yaitu pajak yang pada akhirnya dapat dibebankan atau dilimpahkan kepada orang lain.

b. Menurut sifatnya

Pajak subjektif, yaitu pajak yang berpangkal atau berdasarkan pada subjeknya, dalam arti memerhatikan keadaan diri wajib pajak. Contoh: Pajak Penghasilan. Pajak objektif, yaitu pajak yang berpangkal atau berdasarkan pada objeknya, tanpa memerhatikan keadaan diri wajib pajak. Contoh: Pajak Pertambahan Nilai dan Pajak Penjualan atas Barang Mewah.

c. Menurut lembaga pemungutnya

Pajak pusat, yaitu pajak yang dipungut oleh pemerintah pusat dan digunakan untuk membiayai rumah tangga negara. Pajak daerah, yaitu pajak yang dipungut oleh Pemerintah Daerah dan digunakan untuk membiayai rumah tangga daerah Teori yang mendukung Pemungutan Pajak. Mardiasmo (2013:3) menyatakan terdapat beberapa teori yang menjelaskan atau memberikan justifikasi pemberian hak kepada negara untuk memungut pajak. Teori-teori tersebut antara lain adalah:

1) Teori Asuransi

Teori ini mengibaratkan pembayaran pajak seperti pembayaran premi dalam perjanjian asuransi. Hal tersebut ditujukan untuk mengganti biaya yang dikeluarkan Negara dalam melaksanakan kewajibannya yaitu melindungi keselamatan dan harta benda warga negaranya. Teori ini banyak ditentang karena Negara tidak boleh disamakan dengan perusahaan asuransi.

2) Teori Kepentingan

Menurut teori ini, dasar pemungutan pajak adalah adanya kepentingan dari masingmasing warga Negara, termasuk kepentingan dalam perlindungan jiwa dan harta. Semakin tinggi tingkat kepentingan perlindungan, maka semakin tinggi pula pajak yang harus dibayarkan.

3) Teori Daya Pikul

Beban Pajak yang dibayar harus disesuaikan dengan daya pikul masing-masing orang. Untuk mengukur daya pikul dapat digunakan dua pendekatan: (1) Unsur objektif, dilihat dari besarnya penghasilan dan kekayaan yang dimiliki seseorang, (2) Unsur subjektif, dengan memperhatikan besarnya kebutuhan materiil yang harus dipenuhi.

4) Teori Bakti

Dasar keadilan pemungutan pajak terletak pada hubungan rakyat dengan negaranya. Sebagai warga Negara yang berbakti, rakyat harus selalu menyadari bahwa pembayaran pajak adalah sebagai suatu kewajiban.

5) Teori Asas Daya Beli

Dasar keadilan terletak pada akibat pemungutan pajak. Maksudnya, memungut pajak berarti menarik daya beli darirumah tangga masyarakat untuk rumah tangga Negara. Selanjutnya Negara akan menyalurkannya kembali kepada masyarakat dalam bentuk pemeliharaan kesejahteraan masyarakat. Dengan demikian, kepentingan seluruh masyarakat lebih diutamakan.

\section{Penelitian Terdahulu}

Beberapa penelitian sebelumnya terkait dengan wajib pajak pribadi yaitu Dewi Rina Komarawi dan Mukhtaruddin (2012) tentang analisis tingkat kepatuhan wajib pajak orang pribadi terhadap tingkat penerimaan pajak di Kabupaten Lahat yang menggunakan kepatuahan wajib pajak sebagai variabel dependen dengan menggunakan metode analisis regresi berganda. Dari hasil penlitian, menunjukkan bahwa tidak terdapat pengaruh 
yang signifikan tingkat kepatuhan wajib pajak dalam melaporkan kewajiban perpajakannya terhadap perubahan penerimaan pajak pada KPP Lahat.

Cindy Jotopurnomo dan Yenni Mangoting (2013) tentang pengaruh kesadaran wajib pajak, kualitas pelayanan fiskus, sanksi perpajakan, lingkungan wajib pajak berada terhadap kepatuhan wajib pajak orang pribadi di surabaya. Metode analisis yang digunakan dalam penelitian ini adalah teknik analisis regresi berganda. Hasil menunjukkan secara simultan kesadaran wajib pajak, kualitas pelayanan fiskus, sanksi perpajakan dan lingkungan wajib pajak berada, berpengaruh signifikan terhadap kepatuhan wajib pajak orang pribadi di KPP Sawahan Surabaya.

Nurcahyoni (2011) tentang model moral dan kepatuhan perpajakan wajib pajak orang pribadi. Penelitian ini menemukan bahwa tingkat moral wajib pajak di indonesia belum tumbuh dari motivasi intrinsik individu melainkan paksaan dari faktor eksternal yaitu dari besarnya denda pajak. Metode analisis yang digunakan component based-structural equation modelling (SEM) atau yang dikenal sebagai partial least square (PLS). Hasil penelitian ini menunjukkan bahwa kepatuhan wajib pajak di Indonesia adalah kepatuhan yang dipaksakan yang disebabkan oleh adanya kemungkinan pemeriksaan pajak dan ancaman denda yang tinggi dan belum pada tahap kepatuhan perpajakan secara sukarela.

Oktaviane Lidya Winerungan (2013) tentang sosialisasi perpajakan, pelayanan fiskus dan sanksi perpajakan terhadap kepatuhan WPOP di KPP Manado dan KPP Bitung. Variabel bebas (independent variable) yaitu sosialisai perpajakan, pelayanan fiskus dan sanksi perpajakan, dengan variabel terikat (dependent variable) yaitu kepatuhan wajib pajak orang pribadi. Analisis data menggunakan analisis regresi berganda dengan bantuan software SPSS 17 dengan empat tahap. Hasil penelitian menunjukkan bahwa sosialisasi perpajakan, pelayanan fiskus dan sanksi perpajakan tidak berpengaruh terhadap wajib pajak orang pribadi di KPP Pratama Manado dan KPP Pratama Bitung.

Widi Hidayat Argo Adhi Nugroho (2010) tentang study empiris theory of planned behaviour dan pengaruh kewajiban moral pada perilaku ketidakpatuhan pajak wajib pajak orang pribadi. Penelitian ini menggunakan structural equation modeling (SEM). Hasil penelitian menghasilkan kesimpulan, pertama, sikap terhadap ketidakpatuhan berpengaruh negatif dan signifikan terhadap niat untuk tidak patuh terhadap pajak. Kedua, norma subyektif berpengaruh positif dan tidak signifikan terhadap niat untuk tidak patuh terhadap pajak. Ketiga, kewajiban moral berpengaruh positif dan signifikan terhadap niat untuk tidak patuh terhadap pajak. Keempat, PBC berpengaruh negatif dan tidak signifikan terhadap niat untuk tidak patuh terhadap pajak. Kelima, PBC berpengaruh negatif dan tidak signifikan terhadap perilaku ketidakpatuhan pajak. Keenam, niat seseorang untuk tidak patuh terhadap pajak berpengaruh positif dan signifikan terhadap perilaku ketidakpatuhan pajak.

Siti Munawaroh, Haris Wibisono, Intan Immanuela (2014) tentang faktor-faktor yang mempengaruhi kemauan untuk membayar pajak wajib pajak orang pribadi yang melakukan pekerjaan bebas studi pada KPP Pratama Kota Madiun. Hasil penelitian bahwa kesadaran membayar pajak memiliki tingkat signifikansi sebesar 0,039 , berarti berpengaruh terhadap kemauan membayar pajak, pengetahuan akan peraturan perpajakan memiliki tingkat signifikansi sebesar 0,355, berarti tidak berpengaruh terhadap kemauan membayar pajak, pemahaman tentang peraturan perpajakan memiliki tingkat signifikansi sebesar 0,501 , berarti tidak berpengaruh terhadap kemauan membayar pajak, efektivitas sistem perpajakan memiliki tingkat signifikansi sebesar 0,361,berarti tidak berpengaruh terhadap kemauan membayar pajak, kualitas layanan terhadap wajib pajak dengan tigkat signifikansi 0,508 , berarti tidak berpengaruh terhadap kemauan membayar 
pajak.

Pancawati Hardiningsih dan Nila Yulianawati (2011) Tentang faktor-faktor yang mempengaruhi kemauan membayar pajak. Penelitian ini menggunakan analisis regresi linier berganda. Hasil penelitian Hasil menunjukkan bahwa sikap wajib pajak terhadap kesadaran membayar pajak berpengaruh dan signifikan terhadap kemauan membayar pajak, sikap wajib pajak terhadap pengetahuan peraturan perpajakan tidak berpengaruh terhadap kemauan membayar pajak, sikap wajib pajak terhadap pemahaman peraturan perpajakan tidak berpengaruh terhadap kemauan membayar pajak, persepsi efektifitas sistem perpajakan juga tidak berpengaruh terhadap kemauan membayar pajak, dan untuk kualitas layanan berpengaruh positif terhadap kemauan membayar pajak.

\section{METODE}

Jenis penelitian yang digunakan adalah penelitian kuantitatif. Menurut Sugiono (2015:14), penelitian kuantitatif adalah metode penelitian yang digunakan dalam meneliti terhadap sample dan populasi penelitian.Tujuan penelitian kuantitatif meliputi variabel-variabel dalam penelitian dan hubungan antar variabel tersebut, para partisipan, dan lokasi penelitian.

Lokasi penelitian untuk memperoleh data adalah Kantor KPP Pratama Makassar Selatan. Penelitian ini diperkirakan dalam jangka waktu 2 bulan, mulai dari bulan April 2018 Mei 2018. Selama waktu 2 bulan tersebut digunakan untuk mendapatkan data-data yang relevan agar dapat diolah dan diteliti kemudian dievaluasi hasilnya.

Dalam suatu penelitian diperlukan mengidentifikasikan variabel independen (variabel bebas/berpengaruh) maupun variabel dependen (variabel terikat). Defenisi operasional variabel merupakan defenisi yang mampu memberikan arti da mengspesifikasikan kegiatan agar dapat diukur berdasarkan variabelnya masing-masing.
Dalam penelitian ini yang berperan sebagai $X_{1}$ yaitu Moralitas Wajib Pajak, $\mathrm{X}_{2}$ yaitu Kepatuhan Wajib Pajak, $\mathrm{X}_{3}$ yaitu Pemahaman Wajib Pajak dan Y yaitu Pelaporan SPT.

Populasi dalam penelitian ini adalah seluruh wajib pajak pribadi yang terdaftar di KPP Pratama Makassar Selatan dengan jumlah 147.489 orang sedangkan Sampel dalam penelitian ini adalah wajib pajak yang terdaftar di KPP Pratama Makassar Selatan yang berusia mulai dari 20-60 tahun dan wajib pajak sudah terdaftar minimal 3 tahun keatas, wajib pajak yang dimaksud adalah wajib pajak orang pribadi yang berjumlah 90 orang.

Adapun teknik pengumpulan data dari penelitian ini yaitu:

a. Observasi, metode observasi juga dilakukan dalam penelitian ini, metode ini digunakan dengan maksud mengetahui respon subyek yang diteliti mengenai permasalahan yang ada. Observasi dilakukan secara langsung oleh peneliti (direct observation). Observasi ini digunakan dengan tujuan untuk mengetahui perilaku subyek pada saat observasi berlangsung. Data yang diperoleh dari observasi langsung akan digunakan untuk melengkapi data yang diperoleh dari responden.

b. Dokumen, teknik pengumpulan data dengan dokumen juga digunakan dalam penelitian ini, pemanfaatan informal melalui dokumen-dokumen tertentu yang dianggap pendukung dan bersumber dari laporan-laporan yang berkaitan dengan aspek moralitas, kepatuhan dan pemahaman wajib pajak orang pribadi dalam pelaporan pajak penghasilan.

Teknik analisis data yang digunakan adalah Moderated Regression Analysis (MRA). merupakan aplikasi dari regresi linear berganda dimana dalam persamaan regresinya mengandung unsur interaksi (perkalian dua atau lebih variabel independen) sebagai berikut :

$$
\mathrm{Y}=\alpha+\beta_{1} \mathrm{X}_{1}+\varepsilon
$$


$Y=\alpha+\beta_{1} X_{1}+\beta_{2} X_{2}+\varepsilon$

Keterangan :

$\begin{array}{ll}\mathrm{Y} & : \text { Pelaporan SPT } \\ \mathrm{A} & : \text { Konstanta } \\ \beta & : \text { Koefisien Regresi } \\ \mathrm{X}_{1} & : \text { Moralitas Wajib Pajak } \\ \mathrm{X}_{2} & : \text { Kepatuhan wajib pajak } \\ \mathrm{X}_{3} & : \text { Pemahaman Wajib Pajak } \\ \varepsilon & : \text { Error }\end{array}$

Dalam analisis dan pengolahan data, dilakukan beberapa pengujian yang meliputi uji kualitas data, uji asumsi klasik dan pengujian hipotesis.

a. Uji Kualitas Data

Uji Validitas digunakan mengetahui sah atau valid tidaknya suatu kuesioner. Uji signifikansi dilakukandengan membandingkan nilai $r$ hitung dengan $r$ tabel, jika $r$ hitung $>r$ table dan bernilai positif, maka variabel tersebut tidak valid.

Reliabilitas adalah alat untuk mengukur suatu kuesioner yang merupakan indicator dari variabel atau konstruk. Suatu kuesioner dikatakan reliabel atau handal jika jawaban seseorang terhadap pernyataannya adalah konsisten atau stabil dari waktu ke waktu.

b. Uji Asumsi Klasik

Uji yang dilakukan dalam Uji Asumsi Klasik yatu Uji Normalitas. Uji Normalitas bertujuan untuk menguji apakah dalam model regresi, variabel pengganggu atau residul memiliki distribusi normal. Model regresi yang baik adalah memiliki distribusi data normal atau penyebaran data statistik pada sumbu diagonal dari grafik distribusi normal.

c. Uji Hipotesis

Secara statistik, ketetapan fungsi regresi sampel dalam menaksir aktual dapat diukur dari nilai statistik $t$ dan koefisien determinasinya $\left(\mathrm{R}^{2}\right)$. Suatu perhitungan statistik tersebut signifikasn secara statistic apabila nilai uji statistiknya berada dalam daerah kritis (daerah Ho ditolak dan $\mathrm{Ha}$ diterima).

d. Uji Parsial (Uji t)

Pengujian ini bertujuan untuk memastikan apakah variabel independen secara parsial yang terdapat dalam persamaan tersebut berpengaruh terhadap nilai variabel dependen. Uji $\mathrm{t}$ dilakukan dengan membandingkan anatara t-hitung denga t-tabel. Untuk menentukan nilai t-tabel ditentukan dengan tingkat signifikansi $5 \%$ dan 2 sisi dengan derajat kebebasan $\mathrm{df}=(\mathrm{n}-\mathrm{k}-1)$ dimana $\mathrm{n}$ adalah jumlah responden dan $\mathrm{k}$ adalah jumlah variabel independen. Adapun Kriteria pengujian yang digunakan adalah :

1) Jika t-hitung $\leq$ t-tabel, maka Ho diterima dan Ha ditolak

2) Jika t-hitung $\geq$ t-tabel, maka Ho ditolak dan Ha diterima

e. Uji Determinasi $\left(\mathrm{R}^{2}\right)$

Untuk mengetahui seberapa besar presentase dari variabel independen secara bersama-sama terhadap variabel dependen dapat dilihat dari dari besarnya koefisien determinasi $\left(\mathrm{R}^{2}\right)$ atau $\mathrm{R}$ Square menjelaskan seberapa besar variabel independen yang digunakan dalam penelitian ini mampu menjelaskan variabel dependen.

\section{HASIL DAN PEMBAHASAN}

\section{Hasil}

a. Analisis Data

Kesadaran wajib pajak atas moralitas, kepatuhan dan pemahaman wajib pajak dalam pelaporan pajak penghasilan sangat berpengaruh terhadap pendapatan atas pajak penghasilan dikantor pelayanan pajak khususnya pada KPP Pratama Makassar Selatan, hal ini tercermin pada laporan kinerja penerimaan KPP Pratama Makassar atas PPh pasal 21 dan $\mathrm{PPh}$ pasal $25 / 29$ orang pribadi tahun 2017 yang menggolongkan jenis pajak sebagai $\mathrm{PPh}$ non-migas yang mencanangkan target pendapatan sebesar Rp.789.361.247.959,07 yang berasal dari wajib pajak dengan kinerja penerimaan $\mathrm{PPh} 21$ sebanyak RP 219.935.477.000,02 dan dari penghasilan atas $\mathrm{PPh}$ pasal $25 / 29$ orang pribadi sejumlah RP 57.446.975.000,00. Namun, yang terjadi pendapatan yang diterima pada tahun 2017 hanya sebesar RP.491 858.759.637,00 yang berasal dari 
penghasilan $\mathrm{PPh}$ pasal 21 sebesar $\mathrm{RP}$. yang dapat dilihat pada tabel 1 .

164.108.721.265,00 dan PPh pasal 25/29

orang pribadi sejumlah RP. 20.196.824.940,00

Tabel 1. Kinerja penerimaan KKP Pratama Makassar Selatan pasal 21 dan PPh pasal 25/29 orang pribadi Tahun 2017

\begin{tabular}{llll}
\hline Jenis Pajak & Target & Netto & Output pencapaian \\
\hline PPh Non migas & $789.361 .247 .959,07$ & $491.858 .759 .637,00$ & $67 \%$ \\
\hline 411121 PPh Pasal 21 & $219.935 .477 .000,02$ & $164.108 .721 .264,00$ & $75 \%$ \\
\hline 411125 PPh Pasal 25/29 OP & $57.446 .975 .000,00$ & $20.196 .824 .940,00$ & $35 \%$ \\
\hline
\end{tabular}

Sumber: Data Kinerja Penerimaan KKP Pratama Selatan PPh Pasal 21 dan PPh Pasal 25/29 Orang Pribadi Tahun 2017

Berdasarkan tabel 1 dapat menunjukkan bahwa kinerja penerimaan KPP Pratama Makassar secara keseluruhan hanya menerima output pencapaian sebesar $62 \%$ dari target penerimaan keseluruhan. Hal ini menunjukkan pula bahwa wajib pajak yang membayar atas PPh pasal 21 hanya 75\% dari target dan 35\% dari PPh pasal 25/29 OP.

Pencapaian target penerimaan atas penghasilan wajib pajak orang pribadi tidak hanya terlihat pada penerimaan nominal penghasilan tetapi begitupun dengan status wajib pajak yang terdapat dalam rekapan wajib pajak terdaftar tahun 2017 di KPP Pratama Makassar Selatan yang dapat dilihat pada tabel 2 berikut

Tabel 2. Rekapan Wajib Pajak Terdaftar Tahun 2017 KKP Pratama Makassar Selatan

\begin{tabular}{cccc}
\hline Jenis Wp & \multicolumn{2}{c}{ Status Wajib Pajak } & Total \\
\hline & Non-Efektif & Normal \\
\hline Badan & 5.976 & 11.699 & 17.675 \\
\hline Lainnya & & 2 & 2 \\
\hline OP & 24.522 & 122.967 & 147.489 \\
\hline Pemungut & 45 & 625 & 670 \\
\hline Grand Total & 30.543 & 135.293 & 165.836 \\
\hline Sumber : Data Rekapan Wajib Pajak
\end{tabular}

Rekapan wajib pajak terdaftar di KPP Pratama Makassar Selatan Pada Tahun 2017 sangat jelas menunjukkan bahwa masih kurangnya wajib pajak orang pribadi yang tidak menanamkan moralitas, kepatuhan dan pemahamannya terhadap kewajibannya sebagai wajib pajak, karena dari total wajib pajak orang pribadi sebanyak 147.489 yang menujukkan status wajib pajak orang pribadi yang dalam ukuran normal hanya sebanyak 122.967, selebihnya sebanyak 24.522 masih berstatus non efektif. Meskipun wajib pajak yang menunjukkan status non efektif relative kecil namun hal ini sangat disayangkan karena masih ada warga Negara yang tidak menanamkan theory of planned behavior yang merupakan teori yang berdasar pada niat dari dalam diri individu wajib pajak.

b. Uji Kualitas Data

1) Uji Validitas

Hasil pengujian validitas instrumen pada penelitian ini dilakukan dengan menghitung korelasi antar skor masing-masing butir pernyataan skor total yang dapat dilihat pada nilai pearson correlation, apabila koefisien korelasi positif dan lebih besar dari 0,207 maka indikator tersebut dikatakan valid. Adapun hasil uji validitas akan disajikan pada tabel berikut :

Tabel 3. Hasil Uji Validitas

\begin{tabular}{|c|c|c|c|c|}
\hline Variabel & Item & RHitung & $\begin{array}{l}\mathrm{R} \\
\text { Tabel }\end{array}$ & Keterangan \\
\hline \multirow{3}{*}{$\begin{array}{l}\text { Moralitas } \\
\text { Wajib } \\
\text { Pajak }\left(\mathrm{X}_{1}\right) \\
\end{array}$} & $\mathrm{X}_{1.1}$ & 0,866 & 0,207 & Valid \\
\hline & $\mathrm{X}_{1.2}$ & 0,861 & 0,207 & Valid \\
\hline & $\mathrm{X}_{1.3}$ & 0,711 & 0,207 & Valid \\
\hline \multirow{6}{*}{$\begin{array}{l}\text { kepatuhan } \\
\text { Wajib } \\
\text { Pajak }\left(\mathrm{X}_{2}\right)\end{array}$} & $\mathrm{X}_{2.1}$ & 0,474 & 0,207 & Valid \\
\hline & $\mathrm{X}_{2.2}$ & 0,462 & 0,207 & Valid \\
\hline & $\mathrm{X}_{2.3}$ & 0,601 & 0,207 & Valid \\
\hline & $\mathrm{X}_{2.4}$ & 0,586 & 0,207 & Valid \\
\hline & $X_{2.5}$ & 0,699 & 0,207 & Valid \\
\hline & $X_{2.6}$ & 0,327 & 0,207 & Valid \\
\hline \multirow{4}{*}{$\begin{array}{l}\text { pemahaman } \\
\text { Wajib } \\
\text { Pajak }\left(\mathrm{X}_{2}\right)\end{array}$} & $\mathrm{X}_{2.1}$ & 0,242 & 0,207 & Valid \\
\hline & $\mathrm{X}_{3.2}$ & 0,386 & 0,207 & Valid \\
\hline & $X_{3.3}$ & 0,414 & 0,207 & Valid \\
\hline & $\mathrm{X}_{3} .4$ & 0,536 & 0,207 & Valid \\
\hline
\end{tabular}




\begin{tabular}{lllll}
\hline & & & & \\
\cline { 2 - 5 } & $\mathrm{X}_{3} 5$ & 0,569 & 0,207 & Valid \\
\hline \multirow{2}{*}{$\begin{array}{l}\text { Pelaporan } \\
\text { SPT (Y) }\end{array}$} & $\mathrm{Y} 1$ & 0,414 & 0,207 & Valid \\
\cline { 2 - 5 } & $\mathrm{Y} 2$ & 0,735 & 0,207 & Valid \\
\cline { 2 - 5 } & $\mathrm{Y} 3$ & 0,581 & 0,207 & Valid \\
\hline
\end{tabular}

Sumber: Hasil Olah Data SPSS 22, 2018

Berdasarkan tabel 3 hasil uji validitas diatas, diketahui bahwa dari 18 pernyataan yang digunakan dalam penelitian ini untuk mengukur variabel moralitas, kepatuhan dan pemahaman wajib pajak dalam pelaporan pajak penghasilan sebagai variabel moderasi sebanyak 18 pernyataan dikatakan valid dikarenakan nilai $r$ hitung lebih besar dari $r$ tabel. Dimana nilai $r$ tabel yang digunakan dalam uji validitas ini yaitu sebesar 0,207 sedangkan $r$ hitung di dapat dari hasil pengolahan data menggunakan SPSS versi 22.

\section{2) Uji Reabilitas}

Uji reabilitas data dilakukan dengan menggunakan metode Cronbach's Alpha dimana suatu instrumen dikatakan reliabel bila memiliki koefisien keandalan reabilitas sebesar 0,60 atau lebih. Hasil pengujian reabilitas data dapat dilihat pada tabel berikut:

Tabel 4. Hasil Uji Reliabilitas

\begin{tabular}{ll}
\hline Cronbach's Alpha & N of Items \\
\hline, 845 & 22 \\
\hline Sumber: Hasil Olah Data SPSS 22, 2018
\end{tabular}

Berdasarkan tabel 4 uji reliabilitas dilakukan terhadap item pertanyaan yang dinyatakan valid. Suatu variabel dikatakan reliabel atau handal jika jawaban terhadap pertanyaan selalu konsisten. Jadi hasil koefisien reliabilitas instrument variabel moralitas, kepatuhan, pemahaman wajib pajak dan pelaporan SPT adalah sebesar rll $=0,845$, ternyata memiliki nilai "Alpha Cronbach" lebih besar dari 0,600, yang berarti peranan aspek moralitas, kepatuhan, pemahaman wajib pajak dan pelaporan SPT dinyatakan reliabel atau memenuhi persyaratan.
3) Uji Asumsi Klasik

Pengujian yang dilakukan dalam uji asumsi klasik yaitu uji normalitas data. Pengujian Normalitas data dilakukan untuk memenuhi persyaratan model regresi bahwa data yang diperoleh memiliki sifat normal. Suatu data dikatakan terdistribusi normal jika sebaran data yang ada menyebar merata ke sekitar garis diagonal dan mengikuti arah garis diagonal yang ditunjukkan pada gambar Normal Probility Plot. Hasil dari pengujian normalitas dapat dilihat pada gambar berikut :

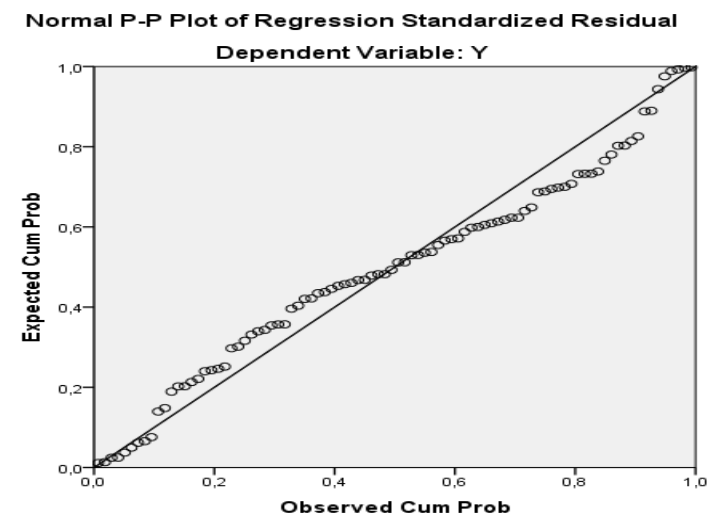

Sumber : Hasil Olah Data SPSS 22, 2018

Berdasarkan gambar diatas, terlihat bahwa titik-titik menyebar disekitar garis diagonal dan mengikuti arah garis diagonal, sehingga model data ini memenuhi asumsi normalitas.

\section{c. Uji Hipotesis}

1) Uji Parsial (Uji t)

Uji Parsial (Uji t) digunakan untuk mengetahui apakah secara parsial variabel moralitas, kepatuhan dan pemahaman wajib pajak sebagai variabel moderasi berpengaruh terhadap pelaporan SPT. Kriteria pengujian yang digunakan adalah dengan membandingkan t-hitung dengan t-tabel berdasarkan tingkat signifikan 0,05 dan 2 sisi derajat kebebasan df $(n-k-1)=(90-3-1)=86(n$ adalah jumlah data dan $\mathrm{k}$ adalah jumlah variabel independen), sehingga t-tabel yang diperoleh dari tabel statistik adalah sebesar 1,662. Apabila t-hitung $\leq \mathrm{t}$-tabel maka Ho diterima, sedangkan apabila t-hitung $\geq \mathrm{t}$-tabel maka Ho ditolak. 
Tabel 5. Hasil uji t

\begin{tabular}{|c|c|c|c|c|c|}
\hline \multicolumn{6}{|c|}{ Coefficient $^{\mathrm{b}}$} \\
\hline \multirow{2}{*}{ Model } & \multicolumn{2}{|c|}{ Understandardized Coefecient } & \multirow{2}{*}{$\begin{array}{c}\text { Standardized } \\
\text { Coefecient }\end{array}$} & \multirow[t]{2}{*}{$\mathrm{T}$} & \multirow[t]{2}{*}{ Sig. } \\
\hline & $\mathrm{B}$ & Std Error & & & \\
\hline (Constant) & 8,219 & 1,410 & & 5,829 &, 000 \\
\hline $\mathrm{X} 1$ & ,499 & ,099 & 739 & 5,032 &, 000 \\
\hline $\mathrm{X} 2$ & ,038 & 049 & 065 & ,791 & ,431 \\
\hline $\mathrm{X} 3$ &, 106 &, 054 &, 151 & 1,960 &, 053 \\
\hline $\mathrm{X} 1 \mathrm{X} 2 \mathrm{X} 3$ & $9,648 \mathrm{E}$ & 000 & ,028 & 204 & 839 \\
\hline
\end{tabular}

Dependent Variale: Pelaporan SPT

Sumber: Hasil Olah Data SPSS 22, 2018

Berdasarkan tabel 5 hasil uji t, maka dapat ditentukan peran aspek moralitas, kepatuhan dan pemahaman wajib pajak terhadap pelaporan SPT dan persamaan regresi linear berganda serta pengujian hipotesis sebagai berikut :

a) Peran moralitas wajib pajak terhadap pelaporan SPT Y $=8,219+0,499+\mathrm{e}$

Angka-angka tersebut dapat diinterpretasikan yaitu Nilai koefisien regresi variabel moralitas wajib pajak $\left(\mathrm{X}_{1}\right)$ bernilai positif sebesar 0,499; artinya setiap wajib pajak khususnya wajib pajak pribadi dalam proses pelaporan SPT akan meningkatkan moralitas wajib pajak sebesar 0,499 dengan asumsi variabel lain bernilai tetap.

b) Persamaan Regresi Linear Berganda $\mathrm{Y}=8,219+0,499+0,038+0,106+\mathrm{e}$ Angka-angka tersebut dapat diinterpretasikan sebagai berikut :

- Nilai konstanta $(\alpha)$ sebesar 8,219 artinya jika variabel moralitas, kepatuhan dan pemahaman wajib pajak diasumsikan bernilai nol, maka variabel pelaporan SPT akan bernilai positif sebesar 8,219.

- Nilai koefisien regresi variabel moralitas wajib pajak $\left(\mathrm{X}_{1}\right)$ bernilai positif sebesar 0,499 artinya setiap peranan moralitas wajib pajak dalam proses pelaporan SPT akan meningkatkan pelaporan pajak penghasilan khususnya orang pribadi sebesar 0,499 dengan asumsi variabel lain bernilai tetap.

- Nilai koefisien regresi variabel kepatuhan wajib pajak $\left(\mathrm{X}_{2}\right)$ bernilai positif sebesar
0,038; artinya setiap kepatuhan wajib pajak dalam pelaporan SPT akan meningkatkan pelaporan pajak penghasilan khususnya orang pribadi sebesar 0,038 dengan asumsi variabel lain bernilai tetap.

- Nilai koefisien regresi variabel pemahaman wajib pajak $\left(\mathrm{X}_{3}\right)$ bernilai positif sebesar 0,106 ; artinya setiap pemahaman wajib pajak dalam pelaporan SPT akan meningkatkan pelaporan pajak penghasilan khususnya orang pribadi sebesar 0,106 dengan asumsi variabel lain bernilai tetap.

\section{2) Pengujian Hipotesis}

Pengujian Hipotesis Pertama $\left(\mathrm{H}_{1}\right)$, terdapat pengaruh peranan aspek moralitas wajib pajak terhadap pelaporan SPT. Diketahui nilai Sig untuk pengaruh $\mathrm{X}_{1}$ terhadap $\mathrm{Y}$ sebesar $0,000<$ 0,05 dan nilai $\mathrm{t}$ hitung 5,032 $>\mathrm{t}$ tabel 1,662 , sehingga dapat disimpulkan bahwa $\mathrm{H}_{1}$ ditolak yang berarti tidak terdapat pengaruh $\mathrm{X}_{1}$ terhadap Y.

Pengujian Hipotesis Kedua $\left(\mathrm{H}_{2}\right)$, terdapat pengaruh peranan aspek kepatuhan wajib pajak terhadap pelaporan SPT. Diketahui nilai Sig untuk pengaruh $\mathrm{X}_{2}$ terhadap $\mathrm{Y}$ adalah sebesar $0,431>0,05$ dan nilai thitung $0,791<$ $\mathrm{t}$ tabel 1,662, sehingga dapat disimpulkan bahwa $\mathrm{H}_{2}$ diterima yang berarti terdapat pengaruh $\mathrm{X}_{2}$ terhadap $\mathrm{Y}$.

Pengujian hipotesis ketiga $\left(\mathrm{H}_{3}\right)$, terdapat pengaruh peranan aspek pemahaman wajib pajak terhadap pelaporan SPT. Diketahui nilai sig untuk pengaruh $\mathrm{X}_{3}$ terhadap $\mathrm{Y}$ adalah sebesar $0,530>0,05$ dan nilai t hitung $1,960>$ 
$\mathrm{t}$ tabel 1,662, sehingga dapat disimpulkan bahwa $\mathrm{H}_{3}$ ditolak yang berarti tidak terdapat pengaruh $\mathrm{X}_{3}$ terhadap $\mathrm{Y}$.

Koefisien Determinasi $\left(\mathrm{R}^{2}\right)$ merujuk pada kemampuan variabel independen (X) dalam menerangkan variabel dependen (Y). Nilai $\mathrm{R}$ koefisien determinasi berkisar diantar nol sampai dengan satu. Komponen-komponen yang terkait dengan koefisien determinasi dapat dilihat pada tabel model summary berikut ini :

Tabel 6. Hasil Uji Koefisien Determinasi $\left(\mathrm{R}^{2}\right)$

\begin{tabular}{ccccc}
\hline Model & $\mathrm{R}$ & $\begin{array}{c}\mathrm{R} \\
\text { Square }\end{array}$ & $\begin{array}{c}\text { Adjusted } \mathrm{R} \\
\text { Square }\end{array}$ & $\begin{array}{c}\text { Std. Error of } \\
\text { the Estimate }\end{array}$ \\
\hline 1 &, 760 &, 0577 &, 558 & 1,04813 \\
\hline
\end{tabular}

a. Predictors: (Constant). X1 x2 x3, Moralitas Wajib Pajak, Kepatuhan Wajib Pajak, pemahaman Wajib Pajak

b. Dependent Variable: Pelaporan SPT

Sumber: Hasil Olah Data SPSS 22, 2018

Hasil uji koefisien determinasi dari tabel 6 nilai $\mathrm{R}$ Square sebesar 0,577 atau $57,7 \%$. Dengan hasil tersebut dapat disimpulkan bahwa variabel dependen dalam penelitian ini yaitu pelaporan SPT mampu dijelaskan oleh variabel moralitas, kapatuhan dan pemahaman wajib pajak sebesar $57,7 \%$ sedangkan sisanya 43,3\% dipengaruhi dan dijelaskan oleh variabel-variabel lain yang tidak digunakan dalam penelitian ini.

Tabel 7. Hasil Uji F

\begin{tabular}{ccclcc}
\hline Model & $\begin{array}{c}\text { Sum of } \\
\text { Squares }\end{array}$ & Df & $\begin{array}{c}\text { Mean } \\
\text { squares }\end{array}$ & F & Sig. \\
\hline Regression & 127,610 & 4 & 31,902 & 29,040 &, $000^{\mathrm{b}}$ \\
\hline Residual & 93,379 & 85 & 1,099 & & \\
\hline Total & 220,989 & 89 & & & \\
\hline
\end{tabular}

a. Dependent Variable: Pelaporan SPT

b. Predictors: (Constant). X1X2X3, X1, X2, X3

Sumber: Hasil Olah Data SPSS 22, 2018

Berdasarkan hasil uji $\mathrm{F}$ pada tabel diatas, diketahui bahwa terdapat peranan moralitas, kepatuhan dan pemahaman wajib pajak terhadap Pelaporan SPT sebagai variabel moderasi sebesar 29,040 dengan nilai signifikansi 0.000 . Nilai $0,000<0,05$ sehingga dapat disimpulkan bahwa moralitas, kepatuhan dan pemahaman wajib pajak berpengaruh signifikan terhadap pelaporan SPT sebagai variabel moderasi.

Hasil hipotesis menyatakan bahwa berpengaruh signifikan. Hasil penelitian aspek moralitas, kepatuhan dan pemahaman wajib pajak berperan secara signifikan terhadap pelaporan SPT sebagai variabel moderasi dengan hasil pengujian hipotesis, diketahui variabel moralitas, kepatuhan dan pemahaman wajib pajak menghasilkan nilai f sebesar 29,040 dengan nilai signifikansi 0,000. Hal ini menunjukkan adanya pengaruh signifikan terhadap pelaporan SPT dan hipotesis diterima.

\section{Pembahasan}

a. Peranan aspek moralitas wajib pajak dalam pelaporan pajak penghasilan/SPT

Pengujian Hipotesis Pertama $\left(\mathrm{H}_{1}\right)$, terdapat pengaruh positif moralitas wajib pajak terhadap pelaporan SPT yang artinya semakin tinggi moralitas wajib pajak, maka dapat meningkatkan atau memperbesar terjadinya pelaporan SPT. Moralitas wajib pajak dapat mempengaruhi tingkat potensi terjadinya pelaporan SPT, serta semakin banyak orang atau individu yang akan dapat meningkatkan pelaporan SPT.

Berdasarkan hasil uji hipotesis yang telah dijelaskan pada hasil penelitian, menunjukkan bahwa moralitas wajib pajak tidak berpengaruh terhadap pelaporan SPT yang diperkuat oleh hasil pengujian yang menunjukkan bahwa t hitung yang diperoleh dari pengolahan data melalui aplikasi SPSS 22 lebih besar dibandingkan dengan t tabel. Hal ini tidak sejalan dengan penelitian yang dilakukan oleh Pancawati Hardiningsih dan Nila Yuliana Wati (2011) dengan judul Faktor-faktor Yang Mempengaruhi Kemauan Membayar Pajak. Dari hasil penelitian yang dilakukan oleh peneliti tersebut menunjukkan bahwa moralitas wajib pajak juga berpengaruh positif terhadap pelaporan SPT. 
b. Peranan aspek kepatuhan wajib pajak dalam pelaporan pajak penghasilan/SPT

Pengujian Hipotesis Kedua $\left(\mathrm{H}_{2}\right)$, terdapat pengaruh positif Kepatuhan wajib pajak terhadap pelaporan SPT yang artinya semakin tinggi Kepatuhan wajib pajak, maka dapat meningkatkan atau memperbesar terjadinya pelaporan SPT. Kepatuhan wajib pajak dapat mempengaruhi tingkat potensi terjadinya pelaporan SPT, serta semakin banyak orang atau individu yang akan dapat meningkatkan pelaporan SPT. Berdasarkan hasil uji hipotesis yang telah dijelaskan pada hasil penelitian, menunjukkan bahwa kepatuhan wajib pajak berpengaruh positif dan signifikan terhadap pelaporan SPT yang diperkuat oleh hasil pengujian yang menunjukkan bahwa $t$ hitung yang diperoleh dari pengolahan data melalui aplikasi SPSS 22 lebih kecil dibandingkan dengan $\mathrm{t}$ tabel.

Hal ini tidak sejalan dengan penelitian yang dilakukan oleh Pancawati Hardiningsih dan Nila Yuliana Wati (2011) dengan judul Faktor-faktor Yang Mempengaruhi Kemauan Membayar Pajak. Dari hasil penelitian yang dilakukan oleh peneliti tersebut menunjukkan bahwa kepatuhan wajib pajak tidak berpengaruh positif terhadap pelaporan SPT.

c. Peranan aspek pemahaman wajib pajak dalam pelaporan pajak penghasilan/SPT

Pengujian Hipotesis Ketiga $\left(\mathrm{H}_{3}\right)$, terdapat pengaruh positif pemahaman wajib pajak terhadap pelaporan SPT yang artinya semakin tinggi pemahaman wajib pajak, maka dapat meningkatkan atau memperbesar terjadinya pelaporan SPT. pemahaman wajib pajak dapat mempengaruhi tingkat potensi terjadinya pelaporan SPT, serta semakin banyak orang atau individu yang akan dapat meningkatkan pelaporan SPT.

Berdasarkan hasil uji hipotesis yang telah dijelaskan pada hasil penelitian, menunjukkan bahwa pemahaman wajib pajak tidak berpengaruh terhadap pelaporan SPT yang diperkuat oleh hasil pengujian yang menunjukkan bahwa t hitung yang diperoleh dari pengolahan data melalui aplikasi SPSS 22 lebih besar dibandingkan dengan $\mathrm{t}$ tabel. Hal ini sejalan dengan penelitian yang dilakukan oleh Pancawati Hardiningsih dan Nila Yuliana Wati (2011) dengan judul Faktor-faktor Yang Mempengaruhi Kemauan Membayar Pajak. Dari hasil penelitian yang dilakukan oleh peneliti tersebut menunjukkan bahwa pemahaman wajib pajak tidak berpengaruh positif terhadap pelaporan SPT.

d. Peranan aspek moralitas, kepatuhan dan pemahaman wajib pajak dalam pelaporan pajak penghasilan/SPT

Berdasarkan hasil uji $F$ yang telah dijelaskan pada hasil penelitian, menunjukkan bahwa nilai f hitung, nilai signifikan serta nilai $f$ tabel memenuhi syarat untuk dikatakan berperan dan signifikan. Dimana setiap keikutsertaan wajib pajak dalam aspek moralitas, kepatuhan dan pemahaman wajib pajak khususnya wajib pajak pribadi akan meningkatkan pelaporan pajak penghasilan/SPT.

Hal ini tidak sejalan dengan penelitian yang dilakukan oleh Pancawati Hardiningsih dan Nila Yuliana Wati (2011) dengan judul Faktor-faktor Yang Mempengaruhi Kemauan Membayar Pajak. Dari hasil penelitian yang dilakukan oleh peneliti tersebut menunjukkan bahwa moralitas, kepatuhan dan pemahaman wajib pajak tidak berpengaruh positif terhadap pelaporan pajak penghasilan/ SPT.

\section{KESIMPULAN DAN SARAN}

\section{Kesimpulan}

Berdasarkan hasil penelitian dan pembahasan yang telah dijelaskan sebelumnya maka penulis mengambil kesimpulan bahwa:

a. Moralitas wajib pajak tidak berpengaruh terhadap pelaporan pajak penghasilan (SPT)

b. Kepatuhan wajib pajak berpengaruh positif dan signifikan terhadap pelaporan pajak penghasilan (SPT)

c. Pemahaman wajib pajak tidak berpengaruh 
terhadap pelaporan pajak penghasilan (SPT)

d. Moralitas, kepatuhan dan pemahaman wajib pajak memiliki pengaruh positif dan signifikan terhadap pelaporan pajak penghasilan/SPT

\section{Saran}

Adapun saran setelah melakukan penelitian ini adalah sebagai berikut:

a. KPP Pratama Makassar Selatan harus meningkatkan sosialisasi kepada wajib pajak untuk meningkatkan moralitas, kepatuhan dan pemahaman terkait pelaporan dan pembayaran penghasilan wajib pajak orang pribadi.

b. Kualitas akan penagihan dalam pembayaran pajak lebih diperketat, sehingga apabila terdapat wajib pajak yang menunggak akan secepatnya membayar tunggakan tersebut.

c. Kantor Pelayanan Makassar Selatan dapat memberikan suatu penghargaan kepada wajib pajak yang cukup patuh dalam melakukan pembayaran, agar dapat merangsang wajib pajak yang lainnya untuk lebih patuh terhadap pembayaran pajak.

d. Kita sebagai wajib pajak perlu meningkatkan kesadaran dari dalam diri sendiri agar nantinya dalam melakukan pembayaran pajak yang terutang dapat dilakukan tepat waktu untuk meningkatkan kinerja penerimaan KPP Pratama Makassar.

\section{REFERENSI}

Budi Wahyono. 2014. Theory Of Planned Beh aviour.(http://www.pendidikanekonomi. com/2014/08/teori-perilaku-yangdirencanakan-theory.html, diakses 28 Juli 2018)

Cindy Jotopurnomo dan Yenni Mangoting 2013. Pengaruh Kesadaran Wajib Pajak, Kualitas Pelayanan Fiskus,
Sanksi Perpajakan, Lingkungan Wajib Pajak Berada Terhadap Kepatuhan Wajib Pajak Orang Pribadi di Surabaya, (Online),vol.1,No.1,(http://pu blication.petra.ac.id/index.php/akuntansi -pajak/article/view/441, diakses 04 januari 20 18)

Dewi Rina Komarawi, D. R, Dan Mukhtaruddin. 2012. Analisis Tingkat Kepatuhan Wajib Pajak Orang Pribadi Terhadap Tingkat Penerimaan Pajak Di Kabupaten Lahat, (OnLine) ,vol.8, No.1 , (http://journal.trunojoyo.ac.id/infestasi/ article/view/1253/1078, diakses 04 januari 2018).

Hardiningsih, Pancawati dan Nila Yulianawati. 2011. Faktor-faktor Yang Mempengaruhi Kemauan Membayar Pajak, (Online) vol. 3, No. 12011 (https://www.unisbank.ac.id/ojs/index.p $\mathrm{hp} /$ fe1/article/download/472/328, diakses pada 23 januari 2018).

Harinurdin, Erwin. 2009. Perilaku Kepatuhan Wajib Pajak Badan. Jurnal ilmu administrasi dan organisasi volume 16 nomor 2 .

Hestanto. 2018. Pengaruh Pengetahuan dan Pemahaman Pajak Terhadap Kepatuhan Wajib Pajak. (https://www.h estanto.web.id/pengaruh pengetahuandan-pemahaman-pajak-terhadapkepatuhan-wajib-pajak/, diakses 28 Juli 2018)

Ilyas, W.B.,Wicaksono, P.2015. Pemeriksaan Pajak. Mitra Wacana Media: Jakarta.

Jatmiko, Agus N. 2009. Pengaruh Sikap Wajib Pajak Pada Pelaksanaan Sanksi Denda, Pelayanan Fiskus Dan Kesadaran Perpajakan Terhadap Kepatuhan Wajib Pajak (Studi Empiris Terhadap Wajib 
Pajak Orang Pribadi Di Kota

Semarang). Tesis Magister. FEB

UNDIP.Semarang

Mira .,dkk. 2017. Praktikum Perpajakan. Fakultas Ekonomi dan Bisnis Universitas Muhammadiyah Makassar.

Munawaroh S., Wibisono H., Immanuela I., 2014. Faktor-Faktor Yang Mempengaruhi Kemauan Untuk Membayar Pajak Wajib Pajak Orang Pribadi Yang Melakukan Pekerjaan Bebas ( Studi Pada KPP Pratama Kota Madiun), (Online), Vol.3/No.1/20

11(http://download.portalgaruda.org/ article.php?article, diakses pada 04 januari 2018)

Nurcahyoni. 2011. Model Moral dan Kepatuhan Perpajakan Wajib Pajak Orang Pribadi, (Online), vol.15, No. 22011(http://eprints.undip.ac.id/38906/1 /jurnal_(JAAI)0001.pdf, diakses pada 04 januari 2018).

Oktaviane Lidya Winerungan 2013. Sosialisasi Perpajakan, Pelayanan Fiskus dan Sanksi Perpajakan Terhadap Kepatuhan WPOP di KPP Manado dan KPP Bitung, (Online), vol.1,No.3(https:/ /ejournal.unsrat.ac.id/index.php/emba/ar ticle/view/2301, diakses pada 04 januari 2018).

Pohan Chairi Anwar, 2016. Pedoman Lengkap Pajak Pertambahan Nilai: Teori, Konsep,dan Aplikasi. Jakarta

Purwono, H. 2010. Dasar-Dasar Perpajakan \& Akuntansi Pajak. Jakarta: Penerbit Erlangga.

Resmi, Siti. 2016. Perpajakan Teori Dan Kasus. Salemba Empat. Jakarta.
Surat Edaran Direktur Jenderal Pajak Nomor SE-103/PJ/2011 Tentang Petunjuk Teknis Serta Tata Cara Penerimaan Dan Pengelolaan Surat Pemberitahuan Tahunan

Sugiyono. 2015. Metode Penelitian Manajemen. Alfabeta. Bandung.

Undang-Undang Republik Indonesia No.28 Tahun 2007 Perubahan Ke-Tiga Atas Undang-Undang No.6 Tahun 1983 Tentang Ketentuan Umum Dan Tata Cara Perpajakan. Jakarta

Undang-Undang Republik Indonesia No.36 Tahun 2008 Tentang Perubahan Keempat Atas Undang-Undang No.7 Tahun 1983 Tentang Pajak Penghasilan. Jakarta

Undang-Undang Republik Indonesia No.46 Tahun 2013 Tentang Pajak Penghasilan Atas Penghasilan Dari Usaha Yang Diterima Atau Diperoleh Wajib Pajak Yang Memiliki Peredaran Bruto Tertentu. Jakarta

Undang-Undang Nomor 28 Tahun 2007 Tentang Ketentuan Umum Dan Tata Cara Perpajakan Memberikan Devinisi Pajak

Undang-Undang No. 7 Tahun 1983 Pasal 4 Ayat 1 Sebagaimana Telah Diubah Dengan Undang-Undang No. 36 Tahun 2008 Tentang Pajak Penghasilan.

Undang-Undang Nomor 28 Tahun 2007 Tentang Ketentuan Umum Dan Tata Cara Perpajakan, Pasal 1 Ayat (2) Wajib Pajak

Undang-Undang Nomor 28 Tahun 2007 Pasal 1 Ayat 6 Tentang Ketentuan Umum Dan Tata Cara Perpajakan. 
AMNESTY: JURNAL RISET PERPAJAKAN

p-ISSN: 2714-6308 | e-ISSN: 2714-6294

pp: 109-125, Volume 1, Nomor 2, November 2018

Undang-Undang Nomor 16 Tahun 2000 Pasal

1 Tentang Surat Pemberitahuan (SPT)

Widi Hidayat Argo Adhi Nugroho 2010.

Pengaruh Kewajiban Moral Pada

Perilaku Ketidakpatuhan Pajak Wajib

Pajak Orang Pribadi , (Online)

voll2, No 22010

(http://jurnalakuntansi.petra.ac.id/inde

php/aku/article/view/18185, diakses

pada 04 januari 2018) 